\title{
Marine Fisheries in Tanzania
}

Fishery resources are a vital source of food and make valuable economic contributions to the local communities involved in fishery activities along the $850 \mathrm{~km}$ stretch of the Tanzania coastline and numerous islands. Small-scale artisanal fishery accounts for the majority of fish catch produced by more than 43000 fishermen in the country, mainly operating in shallow waters within the continental shelf, using traditional fishing vessels including small boats, dhows, canoes, outrigger canoes and dinghys. Various fishing techniques are applied using uncomplicated passive fishing gears such as basket traps, fence traps, nets as well as different hook and line techniques. Species composition and size of the fish varies with gear type and location. More than 500 species of fish are utilized for food with reef fishes being the most important category including emperors, snappers, sweetlips, parrotfish, surgeonfish,

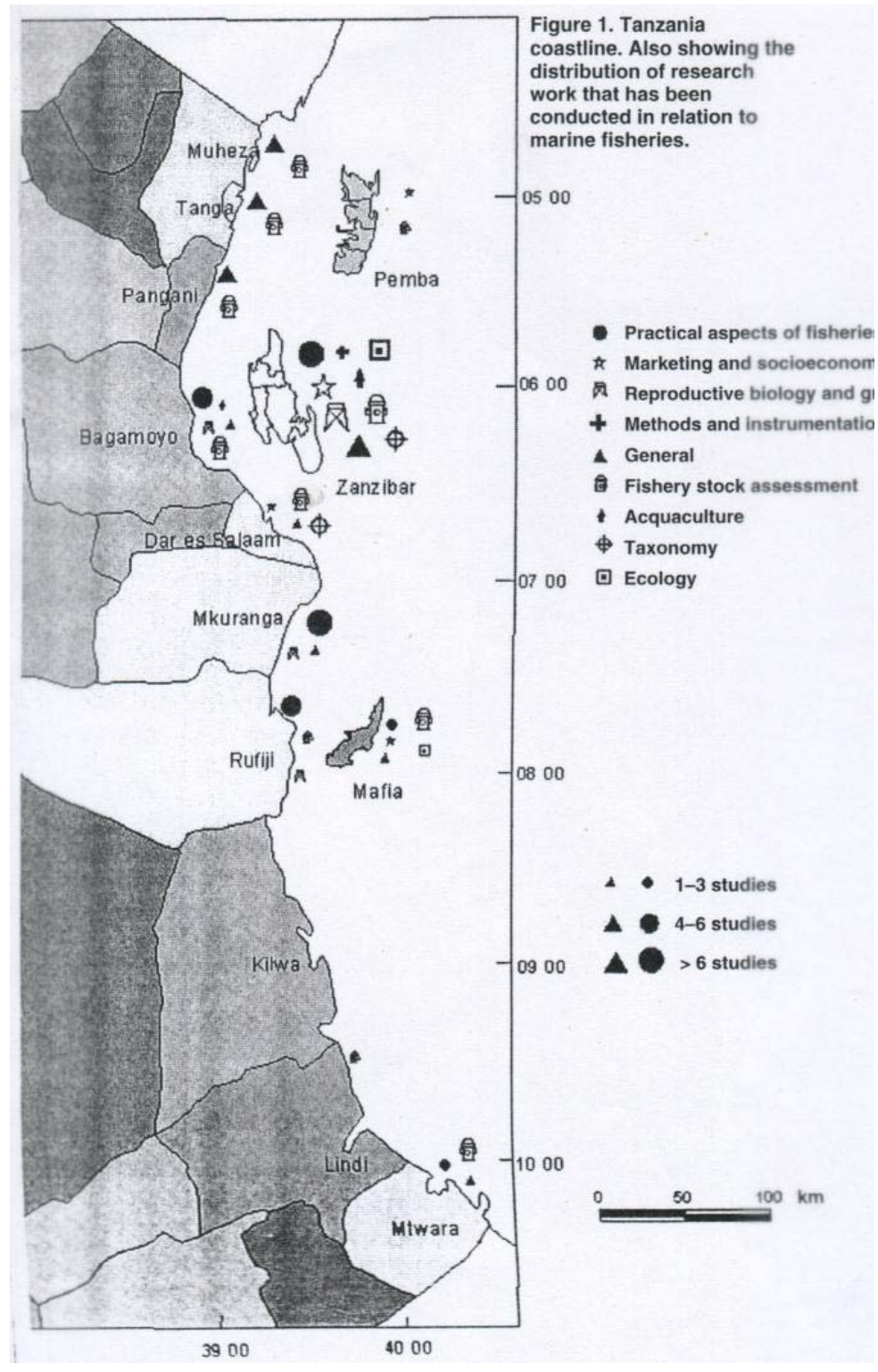

rabbitfish, groupers and goatfish. Most of the fish products are used for subsistence purposes. However, some are exported. Destructive fishing methods such as drag nets and dynamite fishing pose a serious problem as they destroy important habitats for fish and other organisms, and there is a long-term trend of overharvested fishery resources. However, fishing pressure varies within the country as fishery resources are utilized in a sustainable manner in some areas. For this report more than 340 references about Tanzanian fishery and fish ecology were covered. There are many gaps in terms of information needed for successful fishery management regarding both basic and applied research. Most research results have been presented as grey literature $(57 \%)$ with limited distribution; only one-fifth were scientific publications in international journals.

\section{INTRODUCTION}

Being surrounded by rich marine resources the people of the Western Indian Ocean utilize marine products for subsistence, and as a source of income, with fish being among the most important resources. Fishing has been conducted in this area since the dawn of humanity and still continues to be an important coastal occupation.

A large portion of the people of Tanzania (Fig. 1) rely on these resources obtained from a variety of productive marine biotopes which include coral reefs, mangroves, seagrass beds, and estuaries along the 850 Ian stretch of the coastline and around the islands. These coastal waters provide resources of enormous importance for the well being and survival of the communities who are involved in the fishery.

The fishery is typically tropical being small scale and applying a variety of fishing techniques targeting a large number of species. About $95 \%$ of the total marine catch is from this type of fisheries using traditional vessels and gear. An estimated number of full time fishermen operating along the mainland coast is 20000 (1) while approximately 23000 are active in Zanzibar (2). In addition to the fishermen, the fishery also supports a large number of people processing and selling the fish, as well as others who make and repair boats and gear. The contribution of marine fishery to the GDP varies between $2.1-5.0 \%$ for the Tanzania mainland and $2.2-10.4 \%$ in Zanzibar in the last 10 years. In addition to food for the locals, where per capita consumption has been estimated to be between $25-30 \mathrm{~kg}$ person ${ }^{-1} \mathrm{yr}^{-1}$ (3), fishery products are exported overseas. Earnings from exports amounts to USD 12.6 million for mainland Tanzania and USD 0.6 million for Zanzibar (3). The exported products are mainly invertebrates, with most of the export income coming from shrimp.

Clearly, fishery products are important resources for the people of Tanzania. However. much information is still needed to be able to manage the fishery for sustained productivity. The aim of this report is to summarize information on the status of the marine fishery in Tanzania and to highlight existing gaps in the research. The catch composition is de- 
scribed as well as how this varies within the different localities. The different fishing techniques are characterized including equipment selectivity. Data on fish productivity and trends in catches are presented. Threats in terms of overfishing and destructive fishing are highlighted. Gender issues are discussed. On the basis of 340 reports on fishery and fish ecology from Tanzania the status of marine fisheries as a scientific discipline in the country is assessed. Finally, recommendations for research and management are made.

\section{SPECIES}

The number of marine fish species in Tanzania is not known, but estimates of more than 1000 have been made (4) out of which about half of this may be utilized as food or for commercial purposes (5). In a study by Garpe and Ohman, 400 species of fish were recorded within Mafia Island Marine Park down to $10 \mathrm{~m}$ depth (6). Fish resources of special significance include the small pelagic and large pelagic species, demersal fishes, coral reef fishes and the lagoon and intertidal species. The small pelagic species include scad, herring, mackerel, and anchovy. The large pelagic species include spanish mackerel, bonito, yellowfin tuna, barracuda, jack, mackerel and wolf herring. Demersal species include different species of shark, ray, skate, sole, catfish, and shrimp. The coral reef fishes, which include emperors, snappers, sweetlips, parrotfish, surgeonfish, rabbitfish, groupers, and goatfish are the most important group of fishes because they are easily accessible to the traditional fisherfolk. The lagoon and in tertidal pond species include octopus, squid, and a variety of bivalves. These are usually gathered on foot in the littoral zone by women, children and older men.

Species composition and sizes of fish vary with the type of gear, technique and location (Table I). Mgimwa and co-workers (7) recorded 92 species from 29 families from the demo trap fishery in Zanzibar. The most common families were goatfish, rabbitfish, and snapper. Jiddawi and Stanley (8) observed over
60 families of fish from different fishing gears at Matemwe and Mkokotoni. The most common fish are rabbitfish (Siganidae), parrotfish (Scaridae), snapper (Lethrinidae), and unicorn fish (Acanthuridae ).

The lobster fishery is important in Tanzania especially for tourist hotels and restaurants. Common species are Panulirus longiceps, $P$. versicolor, $P$. homan/so P. penicillatlls, and Thenlls orientalis (9) with $P$. ornatus comprising more than half of the catches (10).

Although little information exists on the biology and the ecology of seacucumbers the trade for this species is a comparatively big industry in Tanzania. Up to 30 species have been documented in Zanzibar (II) and 20 in Bagamoyo (12). Twenty-two species are traded, with Holothuria scabra and $H$. nobilis being the most important. However, the stocks of the highly valued sea cucumbers have been overexploited and the most abundant species are lower valued species including Thelonata ananas, Actinopyga echinites, Stichoplls variegatlls and Bohadschia sp.

Collection of sea shells, though discouraged by the authorities, still takes place. More than 150 species of sea shells are collected by fishermen in Tanzania for food and to be sold as curios. A survey by Marshall et ai. (13) revealed that at least 116 species were collected for sale in different markets in Dar Es Salaam. These include 23 species of Conus, 19 species of Cypraea, 4 species of Lambis and I of Tridacna.

\section{LOCATION}

The artisanal fishery is concentrated in inshore shallow waters. This limitation is due to the limited range of the traditional vessels and due to the narrow continental shelf. The continental shelf typically extends to about $4 \mathrm{~km}$ offshore with the exception of the Zanzibar and Mafia channels, where the shelf extends to some $60 \mathrm{~km}$. According to Wiljkstrom et al. (14), the area of the shelf to the $200 \mathrm{~m}$ depth contour for both mainland and Zanzibar combined is about $30000 \mathrm{~km} 2$, which is approximately the size of The Netherlands.

Table 1. Species composition of the most common fish caught in 1998 by the main gears used at Mkokotoni and Matemwe, Zanzibar Island (Ungula) with their maximum (max) and minimum $(\mathrm{mln})$ sizes $(\mathrm{cm})(27)$
Type of gear

Species Mkokotoni

Siganus sutor

Trap Dema

Scarus ghobban

Lethrinus mahsena

Plectropomus maculatus

Leptoscarus vaigiensis

Lethrinus nebulosus

Plectorhinchus schara

Naso hexacanthus

Sphyraena putnamiae

Hemiramphus lutkei

Lethrinus mahsena

L. harak

Hypolophus sephen

Himantura uarnak

Octopus cranes

Sepia latimanus

Lethrinus harak

Diodon holocanthus

Echidna nebulosa

Aetobatus narinari

Lethrinus elongatus

L. microdon

L. rnahsena

Gerres Dyana

Plectorhmchus orientat/is

Lethrinus harak

L. tentjan

Chet/inus chlorurus

Lethrinus harak

Siganus sutor

Hemiramr"us lutkei

Parupeneus indicus

Leptoscarus vaiglens, $s$

Parupeneus pleurostigma

Siganus argenteus

Germs arena
Matemwe

$\max (\mathrm{em}) \quad \min (\mathrm{em})$

28

19

27
13

18

29
67

40

68

62
38

41

38
17

23

127

44
12

94

97

24

187

$14 \quad 11$
14

11
8

13
15

6
8

34
18
47

25

27

27
23
28

16

18
The main and most productive fishing grounds are habitats like coral reefs, mangrove creeks, sea grass beds, and sand banks. Another important resource is the small pelagic fish species. A limited number of fishermen exploit larger pelagic fish in slightly deeper waters. The high seas, or the Exclu,sive Economic Zone (EEZ) that extend over $200 \mathrm{~km}$ out to sea, are so far little exploited and the resource potential is not known. Highly valued larger migratory fish species are found in this area and these are exploited by a few licensed and some illegal fishing vessels. Currently, there are only 12 licensed industrial vessels fishing in the EEZ.

Fisheries is an open-access business and therefore anyone can participate. This has led to an increase in the number of local fishermen as well as an increase in the number of migrating fishermen who travel from their homes to camp and fish in other areas. This movement locally known as dago is an important characteristic of many fisheries in Tanzania. It has resulted in a localized increase of fishing effort in some areas during certain periods of the year and has been the cause of fishery conflicts with local communities. It also poses particu 
lar problems for the management of fisheries, and for the adoption of community-based approaches to management. The dago activity is strongly influenced by the monsoon winds which are seasonally reversing winds. These are the northeast monsoon (kaskazi) which prevails from November to February and is characterized by higher air temperatures and weaker winds. Most fishing activities by artisanal fishermen occur during this period. The other is the southeast monsoon (kusi) which prevails from April to September and is marked by lower air temperature and strong winds sometimes exceeding 5 knots ill-I. Fishing is largely reduced during this period due to unsafe seas. This limits the range and capability of the artisanal vessels. Sometimes the fish

Table 2. Types of fishing gear used by artlsanal fishermen In Tanzania.

\begin{tabular}{|c|c|}
\hline Type of gear & Associated gears \\
\hline $\begin{array}{l}\text { Gill nets } \\
\text { Jarife }\end{array}$ & $\begin{array}{l}\text { Drift gillnet } \\
\text { Demersal gillnet (large mesh) or Sha } \\
\text { Demersal gill nets (small mesh) }\end{array}$ \\
\hline \multicolumn{2}{|l|}{ Cast nets Kimia } \\
\hline $\begin{array}{l}\text { Seine nets } \\
\text { Nyavu }\end{array}$ & $\begin{array}{l}\text { Purse seine } \\
\text { Ring nets } \\
\text { Beach seine }\end{array}$ \\
\hline $\begin{array}{l}\text { Drag nets } \\
\text { Kavogo Kigumi }\end{array}$ & $\begin{array}{l}\text { Any seine net can be used as a } \\
\text { drag net }\end{array}$ \\
\hline
\end{tabular}

Scoop nets Senga

Basket traps

Dema, towe

Large ones (dema), small ones (towe)

Fixed traps

(weir, fence)

(uzio, wando)

Handline Mship/

Longllnes Dhulumati Surface long line

Bottom longline

Troll lines

Kurambaza

Octopus spearing

Mkuki/kljiti

Spear, stick

Harpoons

Bunduki.. mshare

Mosquito net

Utazi wa Juu

Utazi wa chini

Machete (panga)

Mwenge (torch)

Trawl net ermen travel long distances in search of richer fishing grounds. The fishermen of Kojani from Pemba who are famous migrating fishermen are known to travellong,distances as far south as Mozambique and up to the northern border of Kenya.

\section{FISHING TECHNIQUES AND TRADE}

In Tanzania, the artisanal fishery is a small-scale fishery characterized by the use of simple, passive fishing gears which are mostly used in depths not exceeding $30 \mathrm{~m}$ (Table 2). The most common methods are trap fishing and hook and line fishing. The former is mainly conducted by using basket traps of two sizes:

the larger dema trap and the smaller towe trap. Fence traps (uzio) are also used. Dema traps are applied at depths of 10 to $20 \mathrm{~m}$ and the smaller towe traps are used in depths of 3 to $10 \mathrm{~m}$. Usually one fisherman owns about 5 traps but fishermen can have up to 10 traps or more. In terms of hook and line, handlines, longlines and troll lines are utilized. In addition, a range of net types are applied including gill nets, trawl nets, cast nets, seine nets, drag nets, scoop nets, and mosquito nets. Other equipment used for the fishery includes spears, poison, dynamite, and machetes.

Fishing grounds are reached by traditional fishing vessels (Table 3). Fishing vessels mainly utilized are the dhows, mashuas, canoes, outrigger canoes and dinghys. The means of propulsion of these boats are usually paddles, long poles and sails which are used by $90 \%$ of the vessels. A few are fitted with outboard or inboard engines. The number of engines counted in $200 \mathrm{I}$ along the whole mainland coast was 463 outboard and 50 inboard engines (I). Most of these vessels lack cooling and freezing facilities so fishing is limited by both time and distance, thus fisherfolk continue to fish the same grounds as were fished by earlier generations.

Different vessels are used for catching different types of fish. For example the outrigger canoes mainly target nearshore species such as snappers, emperors, rabbitfish, and groupers whereas the dhows and bigger boats catch the offshore larger fish such as marlin, kingfish, sailfish, and tuna (IS).

Fishing activities also take place along the intertidal zones during low spring tides especially by fisherfolk who cannot afford vessels or gear. They usually collect sea cucumbers, shells and octopus by hand or with the assistance of a stick (kijiti). Harvesting of colorful shells is also an important contribution in both food and cash resources of many coastal fa milies. Historically, ornamental
Used in small to medium sized vessels. Have specialized prawn trawling nets with an average length of $38 \mathrm{~m}$ and 5 $\mathrm{cm}$ mesh. Operate in waters 5-15 $\mathrm{m}$ deep. Fish by-catch accounts for part of the catch. 
shells were exported in bulk from Zanzibar. However, a recent decline in exports (from $140 \mathrm{t}$ in 1990 to $30 \mathrm{t}$ in 1997) (10) due to lower demands, caused by environmental concerns, has reduced this fishery. Despite this, shells are still sold locally or in tourist outlets. The favored shells are the trumpet and helmet shells as well as tiger cowries. The opercula of certain shells (e.g. Chico reus ramosus and Pleuroploca trapezium) are also exported to the Middle East. Within mangrove areas the gastropod Terebralia palustris, locally known as suka, is collected for food. The shells of cockles are sometimes ground and used as chicken supplement, while some are used in lime manufacture especially in localized areas in Zanzibar. Sea cucumbers are gathered by hand along the shore or off the sea bed in shallow waters, usually by women and children. The product is gutted, boiled and dried before being exported to the Far East. Virtually no sea cucumbers are consumed locally.

Octopus collection on exposed coral reefs is done primarily during the low water spring tides, usually by sticks or with spears. It is an important inexpensive source of local protein and has a valuable role as a livelihood activity. Mafia Island and Tanga have octopus processing plants which involve considerable number of fisherfolk and have created an overexploitation of the resource. The majority of octopus is sold fresh or iced with some going to the local restaurant industry. The remaining is salted and dried and later exported to Kenya, the Middle East, and Spain. These exports generate income from the levy to the government. Octopus is also an important component on tourist restaurant menus.

In terms of crustaceans, lobster fishing is usually done by net or by hand and sticks; a dead octopus may be used to scare the lobster from its hiding place. The Tanzania mainland exports over 1000 pieces of live lobster to Hong Kong each year. However, the major importing nations of lobsters from Tanzania are Portugal (38 $\mathrm{t}$ in 1996 and $7 \mathrm{t}$ in 1997) and the United Kingdom (7 $\mathrm{t}$ in 1995 and $8.8 \mathrm{t}$ in 1997) (13). Prawn trawling which is conducted on a commercial scale around Bagamoyo/Sadani and the Rufiji Delta in the south of Tanzania target 5 species: Ferropenaeus indicus, Metapenaeus monoceros, Paneus mono don, P. semisulcatus, P. japonicusis. With about 22 operators in action the prawn trawling is the only inshore industrial fishery in Tanzania. Prawns are exported to Europe, the Far East as well as other African countries. Most of the export income comes from prawns.

The middlemen and traders play an important role in the artisanal fishery in providing an opportunity for those fishermen who cannot afford to buy gear or vessels. A middleman usually owns the expensive gear and vessels, such as the seine or gill net and boats or dhows. He partners with the fishermen such that the money obtained from the catch is divided into three parts.

One part goes to the middlemen, one is kept for the maintenance of the boat and gear and one part is for all the fishermen on the boat regardless of their number. The traders then distribute the fish inland. Consequently, the fishermen themselves receive the smallest return.

\section{DESTRUCTIVE FISHING}

The demand for fishery resources has been gradually increasing following the increase in population and tourism development. This has caused an increase in fishing pressure and the use of gear and techniques that are destructive. Most of the destructive methods are prohibited by law but continue to be used due to lack of surveillance, enforcement, and public awareness. Since a large number of the targeted fishes, in particular reef fishes, live in close association with structural features of the bottom $(16,17)$ habitat degradation can have secondary effects on the standing stock of fish decreasing fish numbers $(18,19)$ which can lower the value of the resources for a long period of time (20).
One of the most destructive fishing techniques is dynamiting. This has been practiced in Tanzania for over 4 decades and has been documented by several authors $(12,21,22)$. This activity has contributed to the degradation of habitats and fisheries productivity. Dynamite fishing was reported in the waters surrounding Mafia Island for many years. It was noted however, that with the implementation of the Mafia Island Marine Park (MIMP) the dynamite fishermen started to avoid the area (21).

Other destructive techniques include beach seine fishing and the use of drag nets (juya la kigumi and kavogo) $(23,24)$ as well as the use of sticks and spears (10). The drag net fishery is not illegal even though it breaks corals and other important habitats for fish. Not only is the net dragged over the reef but it is weighted with chains, and sticks are used to hit corals and other structures to chase fish into the net.

The use of poison affects marine organisms indiscriminately including larvae and juveniles (10). The most commonly used poison is an extract from a plant locally know as Utupa (Derris sp.).

Trawling is also a highly unselective fishing technique. The trawlers may not only damage the seabed, but large numbers of fish are caught along with targeted species and discarded as unwanted by-catch (21).

\section{WOMEN AND FISHERIES}

Although women in Tanzania are not conspicuous in the formal fishing sector, their role in other fishing activities is significant. Their commitments are usually restricted to intertidal areas for a limited time of a few hours per day. They do much of the collection of seashells, sea cucumber and octopus usually during spring tides using hands and long wooden sticks or metal rods.

Table 3. Fishing vessels used by artisanal fishermen In Tanzania,

$\begin{array}{ll}\text { Vessel } & \text { Details } \\ \text { Canoe (Mtumbwl) } & \begin{array}{l}\text { Made up from a single log. The bottom is usually flattened for } \\ \text { stability. No outriggers. } \\ \text { Made up from a single log. Have outriggers which provide } \\ \text { additional stability to these vessels. Constructed out of timber } \\ \text { planks. Bow is more pointed than the Mashua and the stern } \\ \text { is rounded or pointed. }\end{array} \\ \begin{array}{l}\text { Chow (Dau) } \\ \text { Constructed out of timber planks. The stern is square. }\end{array} & \begin{array}{l}\text { Very small boat which accompanies bigger boats in the light } \\ \text { attracting fishery. Constructed from plywood and planks. }\end{array} \\ \text { Boat (Mashua) } & \end{array}$

Table 4. export of marine fish and fish products from Tanzania 1998 (1)

\begin{tabular}{lrr} 
Commodity & Weight $(\mathrm{kg})$ & Value in USD \\
\hline Shrimp & 2141722 & 10760315 \\
Octopus & 595783 & 1055637 \\
Lobster & 25999 & 255146 \\
Marine fish fillets & 10321 & 24248 \\
Bech de mer & 872926 & 217277 \\
Crabs & 17882 & 99295 \\
Squids & 12567 & 30484 \\
Sea shells & 154893 & 29859 \\
pelaic fish (EEZ)' & 223639 & 24248 \\
Shar fins & 254 & 4274 \\
TOTAL & 4055986 & 12500783
\end{tabular}

- EEZ large fish caught in the Exclusive Economic Zone 
In addition, 2 types of mosquito nets are used $(25,26)$. The first type is called utazi wa mbavu which is applied during the low tides of each spring tide. The second mosquito net is called utazi wa juu which is applied during neap tides at low tides. The fishing takes place close to shore. Between 20 and 30 women, usually fish together with a daily catch rate $2-17 \mathrm{~kg}$ woman $^{-1}$. The mosquito net fishery is a multispecies fishery with a majority $(61 \%)$ of the specimen being below half the maximum size. The most common species from this fishery are Plotosus lineatus, Atherioll africanus and Gerres oyena usually comprising about $70 \%$ of the catch. The most common species caught by women $<$ It Bagmnoyo are epipelagic shrimps (Acetes spp) locally known as uduvi (12). In addition to the collecting women play an important role in the processing and marketing of fish.

\section{PRODUCTIVITY AND CATCH RATES}

Productivity of fish per unit area in Tanzania was estimated to be $3.8-5.4 \mathrm{t} \mathrm{km}^{-2}$ in $1982-1985$ and $2-3 \mathrm{t} \mathrm{km}^{-2}$ in $1990-1996$, assuming the fishing area is $4000 \mathrm{~m}^{2}(14)$. The CPUE was also estimated to be $19-27 \mathrm{~kg}$ boat $^{-1} \mathrm{day}^{-1}$ in 1982-1985 and 11-12 kg boat ${ }^{-1} \mathrm{day}^{-1}$ in 19901996 assuming 200 fishing days $\mathrm{yr}^{-1}$ (Government National Statistics). This clearly indicates that the fishery resources are declining.

The amount of fish caught, and the duration of fishing, vary from one locality to another. In 4 fishing villages on Zanzibar Island (Unguja) including Chwaka, Nungwi, Matemwe and Mkokotoni the catch rates vesser ${ }^{-1}$ day $^{-1}$ during spring tides were II kg, $36 \mathrm{~kg}, 27 \mathrm{~kg}$, and $30 \mathrm{~kg}$, respectively (27). This is the period when more fishermen are active compared to the neap tides when the catch rates per vessel were observed to be less with about $6 \mathrm{~kg}$ at Chwaka, $12 \mathrm{~kg}$ at Nungwi, $9 \mathrm{~kg}$ at Matemwe, and $21 \mathrm{~kg}$ at Mkokotoni (27).

The number of fishermen in a vessel also varies according to its size which will influence the data on catch rates per fisherman. Usually there are between 3 to 30 fishermen in a vessel depending on the type of fishery. The average catch rates fisher ${ }^{-1}$ day $^{-1}$ at Chwaka, Nungwi, Matemwe and Mkokotoni during spring tides were $6.5 \mathrm{~kg}, 6 \mathrm{~kg}, 10 \mathrm{~kg}$, and $8 \mathrm{~kg}$, respectively. During neap tides the catch rates fisherman-I were less with $2 \mathrm{~kg}$ at Chwaka, $4 \mathrm{~kg}$ at Nungwi, $2 \mathrm{~kg}$ at Matemwe and $5 \mathrm{~kg}$ at
Mkokotoni (27). However, the catch rates vary from one locality to another. It is more pronounced in areas such as Matemwe where there is a fringing reef, which prohibits artisanal fishermen from fishing during neap tides (8).

Catch rates are influenced by the type of gear used as shown in the fishery of 2 fishing villages (Table 5). Bigger harvests were obtained from spear fishing at Matemwc village as opposed to Mkokotoni where more catch came from surrounding' nets. Darwall (21) noted that while most published records of spearfishing report that the catch range is between $0.4-8.5 \mathrm{~kg}$ fisher ${ }^{-1} \mathrm{hr}^{-1}$, he observed in Mtwara, southern Tanzania, that the catch rate was less than $2.4 \mathrm{~kg}_{\text {fisher }}{ }^{-1} \mathrm{hr}^{-1}$. An even lower catch at $0.6-1.3 \mathrm{~kg}_{\text {fisher }}{ }^{-1} \mathrm{hr}^{-1}$ was observed at Matemwe (8). If comparing spearfishing with net fishing the latter showed larger variation with both lower and bigger catches. Darwall (21) recorded the catch rates of net fishing to be $0.2-3.9 \mathrm{~kg}_{\text {fisher }}{ }^{-1} \mathrm{hr}^{-1}$ in the southern part of Tanzania. Similar observations were made by Jiddawi and Stanley (8) at Matemwe, Zanzibar Island (1.2-2.9 kg fisher $\left.{ }^{-1} \mathrm{hr}^{-1}\right)$.

Catch rates of the dema traps have been recorded in different parts of Tanzania (Table 6). According to Horst (28) the total catches from dema trap ranged between $3.2-13.4 \mathrm{~kg}$ fisher$\mathrm{men}^{-1}$ day $^{-1}$. The variation in catch could be due to the traps being set in different biotopes: $85 \%$ were placed on or near coral reefs, $13 \%$ on seagrass beds and $2 \%$ on sand bottoms. In comparing dema traps with other techniques at Chwaka Bay (Zanzibar Island) Tarbit (29) noted that dema trapping was a slightly more efficient technique than handline fishing with a daily catch of $18.6 \mathrm{~kg}$ compared to $16.1 \mathrm{~kg}$. However, using nets fishermen caught $112.8 \mathrm{~kg}$ with an average of $6.6 \mathrm{~kg}$ fisher ${ }^{-1}$ day $^{-1}$. In a similar study by Jiddawi and Stanley (30), they noted that the daily catch of dema traps was $8.3 \mathrm{~kg}$ compared to $11 \mathrm{~kg}$ using handlines and $72 \mathrm{~kg}$ using nets. They also recorded a daily catch of $3.9 \mathrm{~kg} \mathrm{person}^{-1}$ on foot (i.e. fishermen not using any fishing vessel working in the intertidal area). A study conducted at Bagamoyo (12) observed a mean daily catch rate for handlines of $10 \mathrm{~kg}$ boaC', and the mean daily catch rate for beach-seineing method of $50 \mathrm{~kg} \mathrm{boat}^{-1}$. Darwall (21) observed a catch rate of $7 \mathrm{~kg}$ person ${ }^{-1}$ day $^{-1}$ using handlines and a per boat catch of $88 \mathrm{~kg}$ and $84 \mathrm{~kg}$ using nets at Mafia and Songosongo, respectively, while Guard (31) observed a catch

Table 5. Catch rates $(\mathrm{kg})$ of different daytime fisheries at Matemwe and Mkokotoni, 1998 (8).

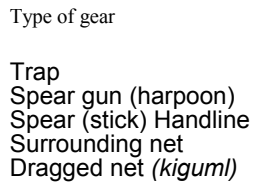
Type of gear
Spear gun (harpoon) Surrounding net Dragged net (kiguml)

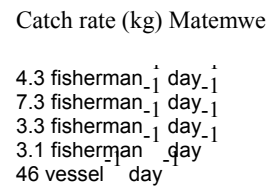

Catch rate $(\mathrm{kg})$ Mkokotoni

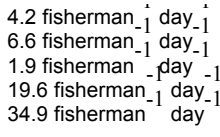

\begin{tabular}{llll}
\multicolumn{2}{l}{ Table 6. Catch rate per Dema trap In Tanzania. } \\
Catch per trap $(\mathrm{kg})$ & Place & Source of data & Reference \\
& & & \\
$1.5-2$ & Mkokotoni 1998 & Artisanal fisherman & $(27)$ \\
4.2 & Matemwe 1998 & Artisanal fishermen & $(27)$ \\
$0.195-0.384 .6$ & Nungwi and Bawe, Zanzibar & Experimental fishing & $(7)$ \\
0.85 & Mtwara & Artisanal fishermen & $(31)$ \\
3.7 & Songo songo & Artisanal fishermen & $(31)$ \\
$0.5-1.2$ & Matemwe 1996 & Artisanal fishermen & $(8)$ \\
$1.1-2$ & Mkokotoni 1996 & Artisanal fishermen & $(8)$ \\
& Matemwe 1995 & Artisanal fishermen & $(30)$ \\
$2.4--4.5$ & Chwaka & Artisanal fishermen & $(29)$ \\
& Tanzania 1985 & Artisanal fishermen & $(29)$
\end{tabular}


rate of $90 \mathrm{~kg} \mathrm{trip}^{-1}$ for the seine net fishery at Mtwara also in the South. This area seems to still be rich in resources compared to other areas in Tanzania.

As stated earlier invertebrates are an important component in the Tanzanian fishery. The average catch per person in the lobster fishery in Tanzania is $5-20 \mathrm{~kg}$ person ${ }^{-1}$ day $^{-1}$ (13) and Darwall (21) reports a catch rate of about $3 \mathrm{~kg} \mathrm{hr}^{-1}$ person $^{-1}$ at Mtwara. The collection of sea cucumber ranges from 8 to 60 individuals person ${ }^{-1}$ day $^{-1}$. Snorkellers and scuba divers collect more and bigger sea cucumbers compared to those who glean the intertidal areas as the former can venture into greater depths. Average catch of shells varies with species: Darwall (21) reported on a mean catch of $10 \mathrm{~kg}$ per person.

\section{STATUS AND TRENDS}

In Tanzania, fish is brought by the boat to a landing site and auctioned on the spot. Beach recorders are used to record the catches in various sites usually about 16 times a month forming the basis of data for the artisanal fisheries production for the country. During the period between 1984 and 1995, the annual fish catch recorded ranged between 45000 and 54000 t for mainland Tanzania (Fig. 2a). However, the inshore fishery is showing signs of overexploitation. The total annual catch in Zanzibar was about $20000 \mathrm{t}$ in 1988, but it has now dropped to less than $15000 \mathrm{t} \mathrm{yr}^{-1}$ (Fig. 2b). This trend is confirmed by detailed long-term studies in some localized areas such as Chwaka Bay, Zanzibar (Fig. 3a-3d) (32). In addition to data from landing sites and other quantitative investigations interviews with older fishermen confirm this trend. However, sufficient data for full resource assessments are not available. Also resource surveys and assessments were last conducted during the 1970s and 1980s, and whilst no assessments have been undertaken since then, resources are believed to have been depleted through overfishing and through the use of destructive methods (see below).

Some fisheries have declined more than others. These include the Zanzibar fishery of small pelagic fish (Fig. 4a), coral reef fisheries in specialized areas (Fig. 4b) and the prawn fishery (Fig. 4c). The catch of small pelagics by the boats of the Zanzibar Fisheries Corporation declined from $600 \mathrm{t}$ in 1986 to $91 \mathrm{t}$ in 1997 and the Corperation has now ceased operations. Shark fin trade in Zanzibar has also declined (Fig. 4d) and some species are now rare in Tanzania waters $(33,34)$. However, according to Barnett (33) shark fin traders give a figure that is more than double the amount that is officially recorded.

Sea shells and sea cucumbers are overexploited along the whole coast and the export of sea cucumbers has declined (Fig. 4e). There are no population or ecological studies of most of the commercial species. However, the traders claim that the accessibility of some of the resources, such as the sea cucumbers and the shells, has reduced tremendously even though the selling continues.

There is a big trade of lobsters and crabs to tourist hotels, restaurants and cruise liners and such crustaceans are showing signs of depletion (unpubl. data). According to the Zanzibar export statistics the export of lobsters from Zanzibar has declined from $23 \mathrm{t}$ in 1993 to 0.7 tin 1997 (Fig. 4f). In addition, the average size of lobster harvested in Tanzania has decreased compared to about two to three decades ago and the supply of lobster has fallen by 33\% since 1988 .

\section{FISHERIES RESEARCH}

The first reports on the marine fishery of Tanzania date back to the beginning of the 20 th century $(35,36)$. The earliest documented reference was from 1929 in a study which examined the marine fisheries of the former Zanzibar Protectorate (35). Research efforts increased in the early 1940s with the establish
Figure 2. Total annual artisanal fish catch trend for Tanzania mainland and Zanzibar.
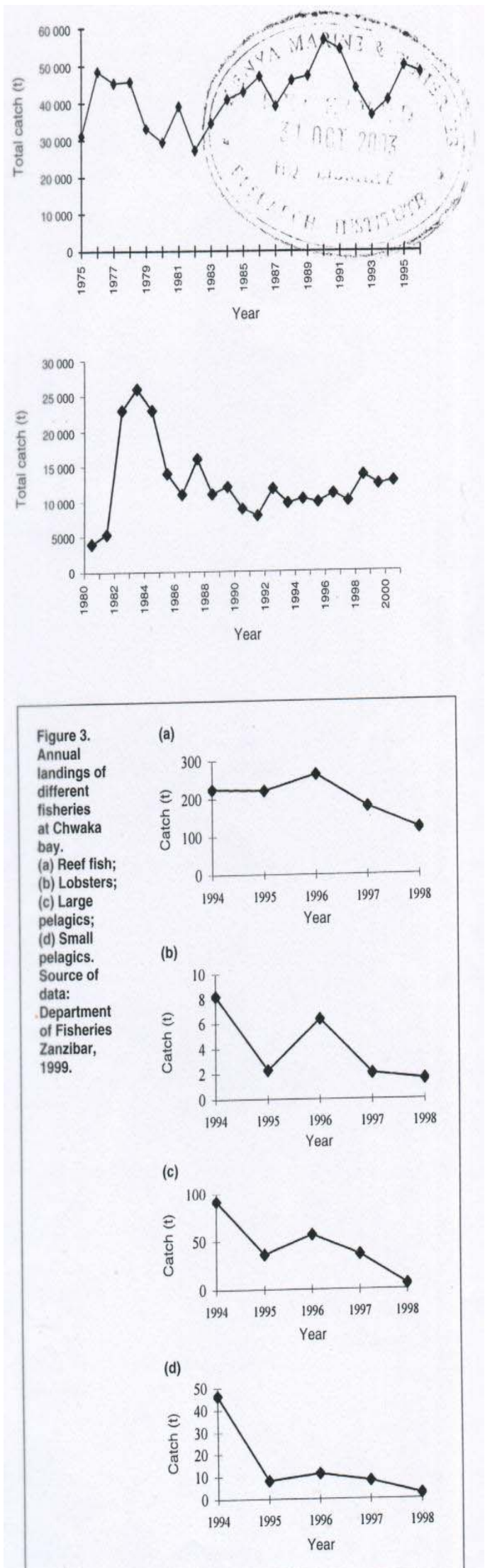


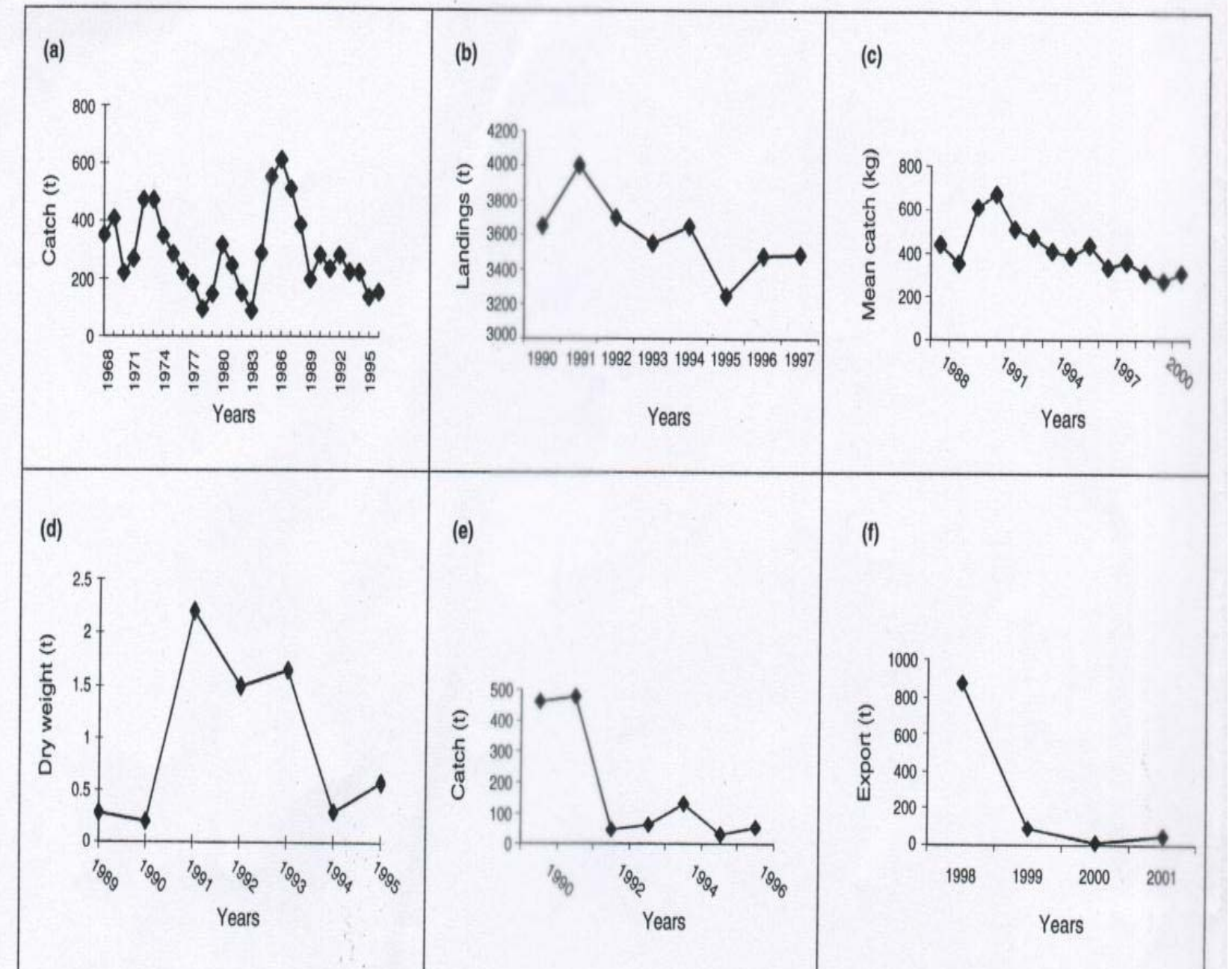

Figure 4. Catch and export trends of selected fisheries In Zanzibar and Tanzania mainland.

(a) The small pelagic fisheries of Zanzibar; (b) the reef fisheries of Zanzibar; (c) the prawn catch rate day $^{-1}$ vesser $^{-1}$ of Tanzania; (d) the of data: Departments of fisheries Zanzibar 1999, and Tanzania mainland 2001.

ment of the East African Marine Fisheries Research Organisation. Subsequently, FAO, Swedish Internationa Development and Cooperation Agency (Sida) and other research geare Tanzania.

Most studies in marine fisheries and fish ecology in Tanzania $(45 \%)$ were conducted in the last decade (1990s) and 33\% in the 1980s (Fig. 5). The earlier research on gear technology and species availability. Although the rate of publications is increasing most of the studies seem to be short term and in "grey literature" aiming at providing baseline information. Out of 340 references on marine fisheries investigated, $40 \%$ were characterized as baseline studies. Most of these were conducted in the 1990s and presented monitoring aspects on fisheries resources. For example, at Matemwe an Mkokotoni $(8,30)$ baseline information was established on species diversity and abundance from the artisana fisheries as well as the type and number of gear used fich tides, luner periodicity and monsoons. The economic and biological importance of specific species was also considered in the same area (37). In Tanga, baseline information was gathered on the status of fisheries resources and the marine environment to be used for management $(38,39)$. Further baseline studies were conducted in Bagamoyo to plan resource usage including not only the fin fishery but also the sea cucumber and mollusk fishery (12)

A significant portion of the "grey literature" comprises of short-term studies and research projects carried out by graduate students in various areas of Tanzania covering a range of topics. Horst (28) examined the dema trap fishery of Tumbatu at Zanzibar Island. Myers (40) presented data on the fence trap fishery including catch composition at Kisakasaka also at Zanzibar Island. Smith (41) and Knox (42) described the pelagic fishery of Nungwi. In the same area, another study examined women's involvement in the fishery (43). The large pelagic fishery was also investigated at Matemwe in which the fishermen themselves conducted the monitoring exercise by completing daily log books (44). Other research projects include the biological aspects of rabbit fish and their mariculture potential (45), the food and feeding habits of Indian mackerel (46), the reproductive biology of the squid (47), the dynamics of the trap fishery $(7,28)$ and the population dynamics of the small pelagic fishery (25). In southern Tanzania several studies have been conducted on the status of fisheries resources $(21,31,48)$.

Frame surveys on fishing units and fishermen have been conducted in Zanzibar by Ngoile (49), Carrara (50), Hoekstra et al. (51), Lyimo et al (2) and others (1). The surveys established the status of fishing effort in terms of number and types of gear, status of fishing effort in terms of number and types of gear,
number and type of vessels, fishermen on foot and those operating using vessels. The surveys established the geographical concentration of the gear and vessels.

Muhando and Ngoile (52) conducted a study on the nursery potential of mangrove ecosystems in Zanzibar Similar studies have been conducted by Amir (53) and Ongera (54). They have also documented length-weight relationships of some of the most common commercial mangrove species.

There are still few studies on quantitative fish ecology in Tanzania. These studies provide information on the actual standing stock of fish underwater. A comprehensive study at Mafia Island Marine Park (MIMP) was conducted by Garpe and Ohman (6) that described the ecology of reef fish communities in the area, specifically how fish assemblages interact with their habitat. Additional studies at MIMP were carried out by Ohman and colleagues (55) and Lindahl with co-workers (56) as they investigated coral mortality effects on fish and Dulvy et al (57) who examined how coral Quantitative studies on fish ecology have also been conducted 
at Zanzibar Island. Bergman and on-workers examined the ecology of Pomacentrus sulfureus (58). They also studied the influence of algal farming on fish communities on the east coast of Zanzibar Island (59). Horrill and colleagues investigated the reef fish communities at Fumba Peninsula (24). Also, McClanahan and co-workers examined the effect of marine reserves, habitat structure and sea urchins on reef fish communities in various sites in Tanzania $(60,61)$.

There are a few experimental studies on the fishery of Tanzania (2.4\%). These experimental studies mainly concern gear development and usage $(62,63)$. However, one comprehensive experiment was performed by Gaudian et al. (64) in which the fishery effects on the standing stock of important commercial fish species were examined.

Most of the fisheries reports $(41 \%)$ were of a review nature mainly presenting general information on fisheries in different parts of the country $(10,65)$. Several reports discussed fisheries development in the country and priorities for management $(66,67)$ or provide general information on the status and trends of marine fisheries in Tanzania $(68,69)$. The reviews also reported on specific fisheries such as the pelagic fisheries (70) and the demersal fisheries $(49,71)$. Conservation issues concerning the artisanal fisheries sector on the Tanzanian mainland have also been reviewed (72) as well as in Misali, Pemba (73) and at Zanzibar Island (74).

In addition to the aforementioned reports there are studies that are more difficult to categorize $(12 \%)$ such as the large fish resources surveys using larger research vessels (75-78). The Fishery Acts, legal aspects and policies also be

long to this category (79-81) as well as sociological and economic studies on fisheries (82). Additional studies were on shark, mollusk and lobster trade in Tanzania $(13,33)$.

Fishery research data were collected using a range of techniques. In terms of fish biology, typically fish morphometrics were monitored $(25,47,83)$. To relate fish population numbers with environmental factors, data on water quality and habitat was compiled and data on fish biology as well as catch and effort data were collected at landing sites (8). Although researchers have followed fishermen to sea (28) few instruments have been employed in fishery studies apart from standard equipment. Fish community composition has been examined using nets such as the beach seine (52) or various trawling techniques (63, $76,78)$, as well as underwater visual investigations $(55,56$, $58,59)$. In addition, fish densities were examined using sonar cquipment (76).

Most information on fisheries was gathered during the rising tide when the fishermen returned from their day at sea. During the monitoring study of the artisanal fisheries of Matemwe and Mkokotoni, however, sampling was done routinely twice a month $(8,27)$. Data has also been collected at night studying the light attracting purse seine fishery for small pelagics

and other fishing techniques $(25,40)$. Other information relevant to a specific fishery was gathered using interviews $(8,84)$.

Although fisheries seems to be widely studied around Tanzania several gaps exist. Most of the studies are conducted in ar eas where research institutions exist or where there are projects. A majority of the research was conducted in Zanzibar, Mafia, Mtwara, Tanga, and Songosongo. A few studies were from Rufiji and Pemba. Many areas have still not been studied.

Most of the reports discuss the general fisheries perspective in Tanzania (18\%). Few discuss the biological aspects of fish. About $14 \%$ of the references present information on specific fisheries such as the shark fisheries or the demersal fisheries in Tanzania. About 3\% references present information on socioeconomic aspects of fisheries. Fisheries development is included in about $5 \%$ of the references. Conservation issues, marine parks and integrated management of fisheries is discussed in $5 \%$ of the references: there is a lot of repetition on these subjects so the number of references should not be misleading.

Presentation of the information varied among the reports, which can be typified as grey literature (57\%) to scientific publications in journals. Out of 340 references investigated about $19 \%$ were scicntific publications in international journals. Others $(15 \%)$ appear in seminar proceedings. Some are in books (I $\%$, videos $(2 \%)$ and others were prepared as in $\mathrm{MSc}$ and $\mathrm{PhD}$ theses $(23,25,45,47,63)$ (Fig. 6).

\section{FUTURE RESEARCH}

In order for the artisanal fisheries to meet the main objectives of providing sustainable fish production and income for fishermen and other people within the industry, specific information is required of the scientists. This information should indicate the

status of each fishery. It should also include the sustainable level or harvest (maximum sustainable yield) as well as identify the optimal size and age composition of the standing stock. To provide this information, it is essential that scientists, in turn, be provided with statistical information on harvest, numbers of fishers, gear types, and vessels, effort (time) and fishing location (8).

Management of the fisheries requires information on the resource. In Tanzania, fisheries statistics collected from the landing sites is still not that reliable and comprehensive enough to provide a complete picture on the status of the resources. Information on the ecology of marine fish communities is sparse and quantitative ecological studies are needed. A data base that covers ecological, environmental, economic and social aspects of fisheries combined with the capacity and expertise to analyze the data is the basic requirement. FU11hennore, there is little data available on socioeconomic and environmental issues. For example, no har

\section{BOX}

\section{Recommendations for research and management information}

A comprehensive research monitoring program on marine resources is required to determine the status, distribution, abundance and value of the resources.

- Data collection from landings and overall data on fishery economics need to be improved.

Specific reference points should be selected along the coast of Tanzania for monitoring purposes.

Stock assessment as well as surveys need to be conducted in the traditional fishing grounds to determine the resource potential.

- $\quad$ There is a great need for studies in quantitative ecology examining species of interest for the fishery.

Biological and growth studies offish need to be done on targeted species.

- Information on maximum sustainable yield is needed which should be related to habitat productivity to provide guidelines on sustainable catch volumes and sensitive areas.

- A Tanzanian fish database should be made that is accessible to the public on the internet.

\section{Management and regulations}

- $\quad$ Existing fisheries laws need to be reviewed and advertised to the general public.

- Fisheries regulations need to be strengthened and enforcement should be improved by providing facilities such as patrol boats, planes and armed officers in order to reduce illegal fishing practices.

- Traditional management should be studied and encouraged if effective.

Conservation of the marine systems should be geared towards benefit to the community who should be educated to appreciate the role of conservation.

- Where catches are decreasing regulations to hinder overfishing should be administered.

- The use of destructive gear such as beach seine / drag nets, poison and dynamite should be banned and enforced. - A ban on collection of immature mollusks, sea cucumbers and crustaceans needs to be imposed and the ban enforced. - There sh"luld be restrictions on visiting fishermen in reserved areas.

- Encourage alternative fishing practices and use of underutilized resources such as deep sea fishing and aquaculture. vest data is available on the amount of fish retained for home consumption. Nor arc there data on the extent of harvesting and gleaning in the intertidal zone. This data is important in $((>$ rIllation for rational planning of these resources. .

Thus there is still information needed for successful management. However, fishery management is much more than research. A challenge for the managers of Tanzania is not only to provide adequate plans, that answer to the actual situation in Tanzania, but also to monitor the success of protective strategies and enforce regulations. Most rules and regulations pertaining to fisheries are old and in most cases not followed, hence, it is difficult to control the situation. Management measures in Tanzania principally relate to the prawn fishery (with a 3month closed season December-March). Improved enforcement is required and this implies the need of a more effective fisheries patrol, and increased community education with regard to environmental and fishery issues.

\section{References and Notes}

1. Anon. 2001. Tanzania mainland fisheries frame survey. Department of Fisheries Re ports, $6 \mathrm{pp}$.

2. Lyimo. E., .Iuma, B.A., Bhai, I. and .Iuma, A.II. I_97. Report of the lishcrics frame survey conducted in Unguja and Pemba. Small Holder Support Project Report, 27 pp.

3. Jiddawi, N.S. 2001. Marine Fisheries in Tanzania. In: Present State of Marine Science. Tanzania TCMP working document, Ngusaru. A. (ed.).

4. Benbow, I.D. 1 7(1. Dangcrous marine animals or East Arrica. East African Literature Bureau. Litho Ltd. Nairobi. $24 \mathrm{pp}$

5. Bianchi, G. I1985;_FAO Species Identification Sheets Fishery Purposes. Field Guide to the Commercial Marine and Brackish-water Species of Tanzania. F AO Document. TCP/URT/4406._Rome, FAO. I_ pp

6. Garpe, K.C. and Ohman, M.C. Coral and fish distribution patterns in Mafia Island Marine Park, Tanzania: fish-habitat interactions. Hydrobiologia. (In press).

7. Mgimwa, F.A., Mgaya, Y.D. and. Ngoile, M.AX. 1999. Dynamics of demo traps finfish catches in the coastal waters of Zanzibar. In: Fisheries Stock Assessment in the Traditional Fishery Sector. The information Needs, Jiddawi, N.S. and Stanley, R. (eds). Proc. National Workshop on the Artisanal Fisheries Sector, Zanzibar. September, 22-24, 1997, Zanzibar, Tanzania Institute of Marine Sciences, University of Dar Es Salaam, Zanzibar, Tanzania. pp 103-101.

8. Jiddawi, N.S. and Stanley, R.D. 1999. A study of the artisanal fishery landings in the villages

of Matemwe and Mkokotoni, Zanzibar. In: Fisheries Stock Assessment in the Traditional Fishery Sector. The information Needs. Jiddawi, N.S. and Stanley, R. (eds). Proc. National Workshop on the Artisana Fisheries Sector, Zanzibar. September, 2224, 1997, Zanzibar, Tanzania Institute of Marine Sciences,

University of Oar Es Salaam, Zanzibar, Tanzania. pp 50-70.

9. Mutagyera, W.B. 1975. A preliminary report on the spiny lobster fishery of Zanzibar. Afr. J. Tropical Fish. 4, 51-59.

10. Muhando, C.A. and Jiddawi, N.S. 1998. Fisheries resources of Zanzibar. Problems and

recommendations. In: Large Marine Ecoystem of the Indian Ocean. Assessment, Sustaillability and

Management, Sherma, H., Okemwa, E. and Ntiba, M.... (eds). Blackwcll Scicnce, pp 232-255.

11. Coleson, J. and Jiddawi, N.S. 1996. The sea cucumbers of Zanzibar. IMS Reports. 30 $\mathrm{pp}$

12. Semesi, A.K., Mgaya, Y.D., Muruke, M.H.S., Msumi, G., Francis, J. and Mtolera, M. 1998. Coastal resource utilization and conservation issues in Bagamoyo, Tanzania. Ambio 27, 635-644.

13. Marshall, N., Milledge, S.A.H and Afonso, S.P. (eds) 2001. Stormy seas for marine invertebrates. Trade in sea cucumbers and lobsters in Kenya, Tanzania and Mozam bique. Trade Review. Traffic. $70 \mathrm{pp}$.

14. Wiljkstrom, 0., Sanders, M. and Khan, R. 1988. A plan for the fishery sector of Zan zibar. A report prepared for the project mission to fisheries in planning, management (Legislation) and development. FAD Document. 94 pp.

15. Griffith, R.D. and Jiddawi, N.S. 1999. Traditional boat building and use in Nungwi. IT Coastal ecology. IMS/SIT Reports, Zanzibar. $38 \mathrm{pp}$

16. Ohman, M.C., Rajasuriya, A. and Svensson, S. 1998. The use of butterflyfishes (Chaetodontidae) as bioindicators of habitat structure and human disturbance. Ambio 27,708-716.

17. Ohman, M.C. and Rajasuriya, A. 1998. Relationships between habitat structure and fish assemblages on coral and sand tone reefs. Env. Bioi. Fish. 53, 19-31.

18. Ohman, M.C., Rajasuriya, A. and Olafsson, E. 1997. Reef fish assemblages in north western Sri Lanka: distribution patterns and influences of fisbing practises. Env. Bio! Fish. 49, 45-61.

19. Rajasuriya, A., Ohman, M.C. and Johnstone, R.W. 1998. Coral and sandstone reef habitats in north-western Sri Lanka: patterns in the distribution of coral communities. Hydrobiologia 362, 31-43.

20. 8erg, H., Ohman, M.C., Troeng, S. and Linden, O. I_98. Environmental economics of coral reef destruction in Sri Lanka. Ambio 27, 627-634.

21. Darwall, W.RT. 1996. Simaya Island. Marine biology and resource use surveys in the Songosongo archipelago. Frontier-Tanzania Marine Research Programme. Project Re port No.3. Societyfor Environmental Exploration. University of Oar Es Salaam.

22. Guard, M. and Masaiganah, M. 1997. Dynamite fishing in southern Tanzania, geo graphical variation, intensity of use and possible solution. Mar. Pollut. Bull. 34, 758 762 .

23. Benno, B.L. 1991. Some Features of the Beach Seine Fishery along the Coastal Dar Es Salaam, Tanzania. MSc Thesis, University of Kuopio, Finland.

24. Horrill, J.C., Seif, I., Ameir, O.A., Omar, S.H., Machano, H., Khatih, A.A., Omar, M and Kibwana, I. 1994. Baseline monitoring survey of the coral reefs and fisheries of the Fumba peninsula, Zanzibar. Zanzibar Environmental Study Series No. 16.

25. Jiddawi, N.S. 2000. Age, Grow/h, Reproductive Biology and Fishery of Rastrelliger kanagurta in Zanzibar, East Africa. PhD Thesis, University of Dar Es Salaam. Tanza nia.

26. Steinhoff, H. 200 I. Women's fishing activities in Nungwi, Zanzibar. SIT Coastal ecol ogy. IMS/SIT Reports, Zanzibar, $40 \mathrm{pp}$

27. Jiddawi, N.S., Yahya, S. and Hamadi, K. 2002. Monitoring of the artisanal fisheries in four fishing villages (Chwaka, Nungwi, Matemwe and Mkokotoni) in Zanzibar. IMS CORDIO Reports, $20 \mathrm{pp}$.

28. Horst, N. 1999. The status of Madema (baskct trap fishing) on TIImbatu island, Zanzi

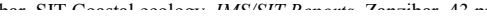


29. Tarbit, J. 1984. Inshore fisheries of the Tanzanian coast. In: Proc. Norad Tanzania Semiliar to review the marine fish stocks and fisheries. Tanzania 6-8 March 1984. Fisheries Division, Dar Es Salaam, Iversen, A.S. and Myklevoll, S. (eds). NORAD, IMR, Bergen, Norway, pp. 29-44

30. Jiddawi, N.S. and Stanley, R. 1997. The artisanal fishery sector of two villages. Matemwe and Mkokotoni, Zanzibar, Tanzania. IMS/CIDA .IMS Reports/97, 61 PI'.

31. Guard, M. 1999. Artisanal fisheries of southern Tanzania, data collection methods, status of fisheries and resource use management. In: Fisheries Stock Assessment in the Traditional Fishery Sector. The information Needs. Proc. National Workshop on the Artisanal Fisheries Seetor, Zanzibar. September, 22-24, 1997, Zanzibar, Tanzania Institute of Marine Sciences, Jiddawi, N.S. and Stanley, R. (eds). University of Dar Es Salaam, Zanzibar, Tanzania, pp. 36-49.

32. Jiddawi, N.S. 1999. Status of the fishery resources of Chwaka bay. In: The Ecology

and Socio Economy of Chwaka Bay. Report prepared for CARE, Tanzania. Mohammed, S. and Jiddawi, N.S. (eds). pp. 24-31.

33. Barnett, R. 1997. The shark tmde in mainland Tanzania and Zanzibar. In: The Trade in Sharks and Shark Products in the Western Indian and Southeast Atlantic Oceans.

Marshall, NT. and Barnctt, R. (eds). TRAFFIC East! Southern Africa. pp. 39-67.

34. Jiddawi, N.S and Shehc, M.S. 1999. The status of shark fishery in Zanzibar, East Af rica. A case study. In: Fisheries Stock Assessment in the Traditional Fishery Sector. The Information Needs. Proc. National Workshop on the Artisanal Fisheries Sector, Zanzibar. September, 22 24, 1997, Zanzibar, Tanzania Institute of Marine Sciences, Jiddawi, N.S. and Stanley, R. (eds). University of Oar Es Salaam, Zanzibar, Tanzania, pp.87-92

35. Bonde, C. von. 1929. Report on a Preliminary Survey on the Marine Fisheries of the Zanzibar Protectorate. By the Government Marine Biologist and Director of the Fisheries and Marine Biological Survey, Union of South Africa, Zanzibar. Government Re port. Government Printer.

36. Bonde, C. von. 1934. A collection of marine fishes from Zanzibar Island. Ann. Nat. Museum 7, 435-458

37. Mhitu, H. and Jiddawi, N.S. 1999. The octopus fishery in Matemwe and Mkokotoni, Zanzibar. In: Fisheries Stock Assessment ill the Traditional Fishery Sector. The informotion Needs. Proc. National Workshop on the Artisanal Fisheries Sector, Zanzibar. September, 22-24, 1997, Zanzibar, Tanzania Institute of Marine Sciences. Jiddawi, N.S and Stanley, R. (eds). University of Dar Es Salaam, Zanzibar, Tanzania, pp.76-80.

38. Makoloweka, S. and Shurcliff, K. 1996. Silencing the dynamite fisheries. Peoples and the Planet 6, 24-25.

39. Horrill, J.C. and Kalombo, H. 1997. Kigombe Reef Fisheries Action Plan. Tanga coastal zone management and conservation programme. TCZCDP. Tanga.

40. Myers, A. 1999. Artisanal fishing in the mangrove intertidal. Two methods in a rura village on Unguja. SIT Coastal ecology. IMS/SIT Reports. $25 \mathrm{pp}$.

41. Smith, J. 1994. Matemwe fishing cooperatives Report No.2 Analysis of the operation "at sea". SIT Coastal ecology. IMS/SIT Reports. 43 pp.

42. Knox. D. 1999. The status of the large pelagic fisheries in Nungwi. SIT Coastal ecol ogy. IMS/SIT Reports. 35 pp.

43. Coleman, E. 1998. Women of Nungwi and their contribution to economic develop ment. Independent study project report. SIT Coastal ecology. IMS/SIT Reports, 45 pp.

44. Richmond, M.D. and Mganwa, G.R. 1994. Matemwe fishing cooperatives monitoring programme. IMS Reports. $22 \mathrm{pp}$.

45. Mziray, G.L 1983. Some Biological Aspects of Siganids (Pisces. Siganidae) and Their Mariculture Potential in Tanzania. MSc Thesis, University of Dar Es Salaam, Tanza nia.

46. Ndawula, LM. 1985. Food and Feeding Habits of Rastrelliger kanagurta in East Af rica. Msc Thesis, University of Dar Es Salaam, Tanzania.

47. Mhitu, H.A. 1997. The Reproductive Biology of the Squid Sepioteuthis lessoniana (Les son 1830) in the coastal waters of Zanzibar. MSc Thesis, University of Dar Es Sa laam, Tanzania

48. Darwall, W.R.T. 1995. The Matia Island Marine Park shark and ray project. Current status and associated problems. Mafia Island Project. Report No.4. Society for Envi ronmental Exploration. University of Dar Es Salaam, Tanzania

49. Ngoile, M.A.K. 1982. A survey of fishing units in Zanzibar and Pemba. Tanzania Notes Records, 88 \& 89, 89-95.

50. Carrara, G. 1985. Artisanal fishery catch assessment survey plan, Zanzibar. SWIOP Document. RAF/79/065/WP/96/E. 27 pp.

51. Hoekstra, T., Ngoile, MA.K., Jiddawi, N.S. and Rotteglia, C. 1990. Census of marine fishing units of Zanzibar in 1989. Regional Project for the Development and Management of Fisheries in the Southwest Indian Ocean. SWIOP Document RAF/87/008/WPI 60/90/E, 118pp.

52. Muhando, c.A. and Ngoile, M.A.K. 1995. Nursery function of coastal ecosystems of

Chwaka Bay and Pajc Coast, Zanzibar. Terminal report of EEC (STD3) Project. $21 \mathrm{pp}$

53. Amir, O.A. 1997. Length weight relationships of selected fish species caught along Mizingani coast and Mapopwe creek in Chwaka Bay, Zanzibar. UDSM/IMS Student Mizingan

reports. $11 \mathrm{pp}$

4. Ongera, P.N. 1997. Frequency distribution and diversity offish species in the Mizingani coastal waters and Chwaka bay, Zanzubar. UDSM/IMS Student reports. $10 \mathrm{pp}$

55. Ohmanan, M.C., Lindahl. U. and Schellen, C.K. 1999. Influence of coral bleaching on the fauna of Tutia Reef, Tanzania, In: Coral reef Degration in the Indian Ocean. Linden, O. and Sporrong, N. (eds), CORDIO, Stockholm. pp.48-52.

56. Lindahl, U., Ohman, M.C. and Schelten, C.K. 2001. The 1997/1998 mass mortality of corals: effects on fish communities on a Tanzanian coral reef. Mar. Pollut. Bull. 42. $127-131$

57. Dulvy, N.K., Stan well-Smith, D., Darwall, W.R.T. and Horrill. J.c. 1996. Coral miti ing at Mafia island, Tanzania: a management dilemma. Ambio 24,358-365.

58. Bergman, K., Ohman, M.c. and Svensson, S. 2000. Influence of habitat structure on the abundance of Pomacentrus sulfureus, a western Indian Ocean reef-fish. Env. Bioi. Fish. 59,243-252.

59. Bergman, K., Svensson, S. and Ohman, M.C. 2001. Influence of algal farming on fish assemblages. Mar. Pollut. Bull. 42. 1379-1389.

60. McClanahan, T.R., Muthiga, N.A. and Kamukuru, A.T., et al. 1999. The effects of ma rine parks and fishing on coral reefs of northern Tanzania. Bioi. Conserv. 89. 161 rine part.

61. McClanahan, T.R. and Arthur, R. 2001. The effect of marine reserves and habitat on populations of East African coral reef fishes Ecol. Appicl. 11. 559-569.

62. Losse, G.F. 1966. Fishes taken by purse seine and dip net in the Zanzibar channel. East Afr. Agric. Forestry J. 32. 50-55.

63. Mahika, G.C. 1992. By-catch Reduction by Grid Separator Grids in Penaeid Shrimp Trawl Fisheries the Case of Tanzania. M.Phil. Thesis, University of Bergen, Norway. $53 \mathrm{pp}$.

64. Gaudian, G., Medley, P.A. and Ormond, R.A.F. 1996. Estimation of the size of coral reef fish population. Mar. Ecol. Prog. Ser. 122. 107-113.

65. Maembe, T.W. 1988. The status of the fisheries industry in Tanzania. National Semi liar on Fisheries Policy and Planning. University of Dar Es Salaam.

66. Boerema, LK. 1981. Development of the fishery in Zanzibar. Technical Report. FAD Rome. $13 \mathrm{pp}$

67. FAO 1982. Planning fisheries development in Zanzibar, Tanzania. Project findings and recommendations. Terminal Report. $33 \mathrm{pp}$.
. Nhwani, LB. 1991. The marine artisanal fisheries of Mainland Tanzania. TAFIRI Res. Bull. 3. 22-26.

69. Bryceson, I. 1994. Some reflections on issues related to marine ecology and fisheries along the coast of Tanzania. Samudra 9, 32-37.

70. Nhwani, LB. and Makwaia, E.D. 1988. Aspects of the fishery biology of small pelagic fishes at Oar Es Salaam, Tanzania. Fish byte 6, 7-10.

71. Pratap, H.B. 1982. Demersal fisheries in Tanzania: status and development strategy. University Sci. J. (University of Dar Es Salaam) 8, 11-19.

72. Mwamsojo, G. 1999. The role of national environment management council (NEMC) in artisanal fisheries conservation in Tanzania. In: Fisheries Stock Assessment in the Traditional Fishery Sector. The information Needs. Jiddawi, N.S. and Stanley, R. (eds). Proc. Natl Workshop Artisanal Fisheries Sector, Zanzibar. Sep., 22-24, 1997. Institute of Marine Sciences, University of Dar Es Salaam, Tanzania. pp. 126-134.

73. Richmond, M.D. and Mohammed, S.M. 2001. A review of the fisheries of the Misali Island Marine Conservation Area (M]MCA), Pemba, with recommendations for monitoring. CARE Tanzania. Commission for Natural Resources. Zanzibar, Tanzania. $67 \mathrm{pp}$

74. Jabir, K.M., Khatib, A:and Machano, H.A. 1999. Environmental Conservation in the artisanal fisheries sector. In: Fisheries Stock Assessmelll in the Traditional Fishery Sector. The information Needs. Jiddawi, N.S. and Stanley, R. (eds). Proc. Natl Workshop tor. The information Needs. Jiddawi, N.S. and Stanley, R. (eds). Proc. Natl Workshop
Artisanal Fisheries Sector, Zanzibar. Scp., 22-24, 1997, Zanzibar, Tanzania Institute of Artisanal Fisheries Sector, Zanzibar. Scp., 22-24, 1997, Zanzil
Marine Sciences, University of Dar Es Salaam. pp. 163161.

75. LJirkett, L 197M. Western Indian Ocean fishery resources survey. Report on the cruises of R/V Prof. Mesyatsev, December 1975-June 1976/July 1977. Tech. Rep. Indian Ocean Programme $21.97 \mathrm{pp}$.

76. Iversen, S.A., Myklcvol, S., Lwiza, K. and Yonazi, J. 1984. Tanzania fish resources in the depth region 10-500 m investigated by R/V "Dr. FridtjofNansen". In: Proc. of the Norad Tanzania Seminar to Review the Marine Fish Stocks and Fisheries. Tanzania, 6-8 March 1984. Iversen, A.S. and Myklevoll, S. (eds). Fisheries Division, Dar Es Salaam. NORAD, IMR Bergen Norway. pp. 45-83.

77. Van Nierop, M. 1987. Analysis of trawl data of the training vessel 'Mafunzo' for 1986. Report. 36 pp.

78. Msumi, G.D. 1988. Results of bottom trawl surveys for demersal fishery in the Zanzi bar Channel. In: Proc. Workshop on Bioproductivity of the Marine Coastal Waters of Eastern Africa. Mainoya, J.R. (ed.). Oar Es Salaam, 18-20 January 1988. PI'. 19-101.

79. Maembe, T.W. 1984. The relationship between marine fisheries research and fisheries policy, planning, management and education. Proc. Norad Tanzania Seminar to Review
the Marine Fish Stocks and Fisheries. Tanzania 6-8 March 1984. Iversen, A.S. and Myklevoll, S. (eds). Fisheries Division, Dar Es Salaam, NORAD, IMR Bergen Norway. pp.169-174.

80. Christy, LC. 1981. Fisheries legislation in Zanzibar. FAO Reports. Rome Italy.

81. Lamwai, M.R.M. and Mashangur, E. 1988. Legal aspects of dynamite fishing in Tanzania. Investigation related to the protection and conservation of coastal marine resources in the Dar Es Salaam area. National Environment Management Council Reports, 1988. pp.

82. Soley, N. ]997. Socio-economic profile of the fisheries of Misali Island, Pemba. The Environment and Development Group Report, Oxford, England. $36 \mathrm{pp}$.

83. Rubindamayungi, M.S.T, 1983. The Biology of the Blue Speckled Parrotfish Leptoscams vaigiensis Occurring Along the Coast of Tanzania. MSc Thesis, University of Dar Es Salaam, Tanzani

84. Anderson, J. and Ngazy, Z. 1995. Marine resource use and the establishment of a ma rine park. Mafia Island, Tanzania. Ambio 24; pp. 475-481.

85. The authors wish to thank the support from TCMP, the Institulo of Marine Sciences (UDSM) and the Sida/SAREC Bilateral Marine Science Programme between Sweden and Tanzania for logistic and financial support. Our profound thanks to Prof. Allan Whittick of Memorial University of New Foundland, Dr. Matt Richmond of Allan Whittick of Memorial University of New Foundland, Dr. Matt Richmond of
Samaki Consultancies and Dr. Rick Stanley of the Pacific Laboratory Nanaimo for valuables comments on the manuscript. We wish also to thank Saleh Yahya and Hamad Khatib for their assistance in fieldwork.

Dr. Narriman S. Jiddawi is a research fellow and Associate Director of the Institute of Marine Sciences, University of Dar Es Salaam. She holds a MSc and $\mathrm{PhD}$ in fisheries science. Her work involves research in fisheries management, aquaculture as well as social aspects and women involvement in fisheries. Her address: Institute of Marine Sciences, University of Dar-esSalaam, P.O. Box 668, Zanzibar. E-mail: jiddawi@ims.udsm.ac.tz

Marcus C. Ohman, PhD, is a senior scientist and lecturer at the Department of Zoology, Stockholm University, Sweden. His research interests are in marine ecology, fisheries, disturbance effects on the marine biota, environmental economics and coastal zone management. He is coordinating and acting research advisor for Sida supported projects in marine sciences.

His address: Department of Zoology, Stockholm University, SE-10691 Stockholm, Sweden.

E-mail: marcus.ohman@zoologi.su.se 